\title{
What Can We Learn from Our Learners' Learning Styles?
}

\author{
Bokyung Lee ${ }^{1} \&$ Haedong Kim ${ }^{1}$ \\ ${ }^{1}$ TESOL Department, Hankuk University of Foreign Studies, Seoul, Korea \\ Correspondence: Haedong Kim, TESOL Department, Hankuk University of Foreign Studies, Seoul, 130-792, \\ Korea. Tel: 82-10-8448-3715. E-mail: khd@hufs.ac.kr
}

Received: February 12, 2014 Accepted: July 2, 2014 Online Published: August 14, 2014

doi:10.5539/elt.v7n9p118 URL: http://dx.doi.org/10.5539/elt.v7n9p118

\begin{abstract}
This study aims to investigate Korean university-level EFL learners' learning style preferences. The characteristics of their learning style preferences and implications for effective English learning were examined through the quantitative analysis of 496 subjects' responses to a learning style survey and their English achievement and term-end performances. The findings indicate that Korean learners' auditory style preference is noticeable, and visual and individual learning styles are also considered to be primary learning styles, whereas tactile, kinesthetic, and group learning styles are less favored. This suggests that the learners want to learn English with more emphasis on a visual-driven independent style than on an experience-driven collaborative style. Additionally, a majority of the learners tend to maintain or reinforce their preferences throughout the course, and they tend to obtain relatively better English achievement results than learners who substantially change their preferences. In terms of learners' awareness of their identified learning styles, the findings show that style-aware group performed better than the unaware group. However, any generalization regarding the relationship between learning styles and English achievement or performance should be avoided. Importantly, generalizations regarding ethnic groups' learning style preferences should be discussed cautiously; instead, learning styles should be discussed relative to the learning context.
\end{abstract}

Keywords: learning styles, auditory, visual, tactile, kinesthetic, individual, group

\section{Introduction}

Variables in language learning encompass a wide range of learner characteristics such as intelligence, aptitude, personality, motivation, learning style, learning strategy, and so on. Despite increased interest in individual differences in language learning, there has been a dearth of efforts to discuss such learner individual differences in depth and to apply knowledge gained to practical areas such as curriculum development, teaching methodology, and materials selection in the field of ELT. By focusing on learning styles as an instance of individual difference, the present study aims to investigate how learners' learning style preferences are identified and whether the information gathered provides any insight into learners' effective English learning.

Dörnyei (2005) noted six types of mismatch between learning styles and other learning-generating factors that cause learning difficulties in practice: mismatch between learning styles and teaching styles, the syllabus, language tasks, learners' beliefs about learning, learning strategies, and learners' abilities. He argued that "some sort of style harmony would be beneficial in many respects for teachers and learners alike" (p. 155). There is little doubt that a well-matched combination of learning styles and the above-mentioned factors should contribute to learning effectiveness.

It is believed that the mismatch between learning styles and syllabus/language tasks can be minimized by gathering information from learners through discussing identified learning styles with students and empowering them to adapt to various approaches (Oxford \& Anderson, 1995). That is, knowledge of students' learning styles is the first step for teachers to provide students with more effective learning environments. Teachers' awareness of students' learning style preferences may allow them to provide learners with more research-based instruction rather than merely conventional approaches and methods. Moreover, learners may also benefit from knowledge of their own learning style preferences. Cohen (2002) suggested that learners be invited to engage in style-stretching, adding learning styles in a flexible manner; thus, they may make use of multiple leaning styles for more effective language learning. They can become more skilled learners who make the best of language materials that incorporate their learning style preferences. Having a more complete knowledge of their learning 
styles ultimately enables learners to become self-directed and autonomous.

In this context, the research question of the present study is "Do Korean university-level EFL learners' learning styles exist, and if so, what are the distinctive characteristics and implications of their learning style preferences?" followed by three sub-questions: 1) Do the learners have a consistent major learning style(s) or modify them throughout the English language course? 2) Is consistency or modification of a major learning style(s) related to their English achievement in the course? 3) Does the learners' awareness of their identified learning style(s) help them achieve better learning results in the course?

\section{Literature Review}

\subsection{Concept of Learning Styles}

The term learning style is sometimes used interchangeably for cognitive style. Cognitive style refers to "an individual's preferred and habitual modes of perceiving, remembering, organizing, processing, and representing information" (Dörnyei, 2005, p. 124). For example, whether an individual is field-dependent/ field-independent, holistic/analytic, deductive/inductive, and impulsive/reflective determines his or her cognitive styles. Learning styles are related to educational contexts while cognitive styles are rather neutral concepts (Brown, 2000; Dörnyei, 2005). In other words, learning style refers to learning-driven cognitive styles.

The concept of learning styles in language learning has been examined by many researchers. Brown (2000) described it as "a term that refers to consistent and rather enduring tendencies or preferences" (p. 113). He added that learning styles are educationally-driven cognitive styles, i.e. affectively or psychologically blended cognitive styles. Oxford (2001) defined language learning styles as "one's general approach to learning a language" (p. 359). She distinguished learning styles from learning strategies in that the latter are more likely specific thoughts or practices learners apply to facilitate their language learning. Other definitions have been offered such as "cognitive, affective, and physiological traits that are relatively stable indicators of how learners perceive, interact with, and respond to the learning environment" (Keefe, 1979, p. 4), "the overall patterns that give general direction to learning behavior" (Cornett, 1983, p. 9), and "internally based characteristics, often not perceived or consciously used by learners" (Reid, 1998, p. ix).

It is generally understood that language learning style refers to how a language learner receives, retains, and retrieves new information, knowledge, and skills in language learning situations. Learning styles can be either an inherent quality or a nurtured attribute, but it has been acknowledged that the status of a learning style is generally stable and consistent inside each individual language learner. Dörnyei and Skehan (2003) noted that learning style is one's inclination that is deeply rooted, but they also emphasized "some capacity for flexibility, and scope for adaptation of particular styles to meet the demands of particular circumstances" (p. 602). Each learner has a preferred learning style, and, therefore, knowledge of learners' preferred learning styles can provide learners, teachers, educators, and researchers with useful and important information.

A number of researchers have provided dimensions to characterize learning styles. In the past, the difference between field dependent and field independent learners was the main focus of many studies (Chapelle \& Green, 1992; Chapelle \& Roberts, 1986; Hansen, 1984; Hansen \& Stanfield, 1981). Dörnyei (2005) noted that learning style instruments were developed for practical rather than for research purposes, suggesting that they have "not been fine-tuned for scientific measurement purposes" (p. 141). Nevertheless, Reid's (1995) Perceptual Learning Style Preference Questionnaire (PLSPQ), Oxford's (1993) Style Analysis Survey (SAS), Cohen, Oxford, and Chi's (2001) Learning Style Survey (LLS), and Ehrman and Leaver's (2003) Construct are the best-known and most widely-used instruments. Reid (1987) introduced perceptual learning styles, and her survey was designed to assess ESL learners' styles and has been widely used for non-native learners. For the present study, this instrument is employed for its high feasibility and user-friendliness.

\subsection{Previous Studies on Learning Styles}

Arguments against learning styles are either theory-based or practice-based. In terms of theory, on one hand, some researchers and educational psychologists criticize the lack of a conceptual framework for learning styles. Stahl (1999) argued that what learning styles means is unclear; it is rather blended or a confused concept. Accordingly, it can refer to learning preferences or cognitive styles, and some understand it to refer to personality types or sometimes as aptitude. An additional quagmire is the lack of generally and widely accepted measurement instruments (Dörnyei, 2006). On the other hand, some have criticized learning styles for not providing any practical or substantial grounds for learners and teachers. For example, several studies confirmed that matching learners' styles with a teacher's methodology or materials had little or no effect on the learners' achievement (Arter \& Jenkins, 1979; Kampwirth \& Bates, 1980; Kavale \& Forness, 1987; Snider, 1992; Tarver 
\& Dawson, 1978). According to these studies, learners exhibited different styles in different subjects and also based on when they answered the questionnaire. Dörnyei (2005) claimed that both learners and teachers can potentially benefit from an increased awareness of learning styles but there are some serious application problems in practice.

Despite these skeptical perspectives, interest in learning styles in second language research has not disappeared. Rather, there has been renewed interest since the late 1990s (Dörnyei, 2006). Dörnyei (2006) stated that the reason why researchers' interests have not withered away is that there is "something genuinely appealing about the notion" (p. 55). He also expressed that the current state of learning style research is due to insufficient knowledge rather than its inadequacy as a viable scientific concept.

Many researchers have contributed to learning style research in relationship to SLA for decades. Two types of research have focused on albeit overlapping areas in some studies: style identification and relationship analysis between learner style and other variables. The first type of learning style research aims to identify students' learning styles using a questionnaire instrument (Brown, 1973; Hansen \& Stansfield, 1981; Hyland, 1994; Y. Kim, 1995; K. Kim, 2007a; K. Kim, 2007b; Lee, 1995; Melton, 1990; Oxford, 1993; Reid, 1987; Willing, 1988). Among them, Willing's study (1988) is considered to be one of the most intensive and exhaustive investigations (Skehan, 1991; Tudor, 1996). His project was conducted by The Adult Migrant Education Service of New South Wales (AMES). A total of 517 migrant language learners participated in the survey research that included preliminary interviews, a literature review, and trialing and revision of the questionnaire. Based on a FI/FD dimension, the researcher added an active/passive dimension. The participants were divided into four categories: FI-active, FI-passive, FD-active, and FD-passive. Quadrants were interpreted as communicative-oriented, analytic, concrete, and authority-oriented, each of which captured $40 \%, 10 \%, 10 \%$, and $30 \%$ of participants. It is noteworthy that the researcher used the research findings practically to develop a new training program at AMES. It is true that research and practice should interact with each other.

It seems possible to investigate the effect of cultural background on formulating learning styles (Song \& Oh, 2011). Park (2002) surveyed 857 high school students from five different ethnic backgrounds who were learning English and reported that there were significant differences in preferences for group or individual learning styles according to their ethnic backgrounds. Joy and Kolb (2009) investigated 533 respondents from seven different countries and found out that a preference for abstract or reflective learning styles were dependent upon students' ethnic backgrounds. However, we should note that learners within one ethnic group can have individual preferences (Irvine \& York, 1995). Moreover, individuals' learning styles may be influenced not only by cultural factors but also by learners' internal factors, such as attitude or motivation (Ma \& Oxford, 2014). In this sense, when we check the preferred learning styles within one ethnic group, we should focus on the differences of individuals' learning styles in a particular context.

Reid (1987) investigated 1,388 university undergraduate and graduate students' (1,234 NNSs and 154 NSs) learning styles using a thirty-item questionnaire. The participants were diverse in terms of age, gender, major, mother tongue, TOEFL scores, length of time in the U.S., and length of time studying English in U.S. She classified them into six perceptual learning styles: visual, auditory, kinesthetic, tactile, individual, and group. The major finding is that NSs and NNSs were often significantly different in their learning preferences. Specifically, ESL students' preferred styles were kinesthetic and tactile, and most of the participants preferred individual learning to group learning. Korean students had the highest mean score in visual learning style preference among nine language background groups. In addition, Arabic, Chinese, and Korean students appeared to have multiple learning style preferences.

Lee (1995) and Kim (2007a) used Reid's PLSPQ in their respective studies intended for Korean EFL university students. The results of the two studies were quite different. Lee (1995) investigated 74 social science and engineering majors and found that an individual learning style was preferred to a group style and only these two learning styles were considered major learning style preferences. There were no negative learning style preferences, and social science majors showed significantly more kinesthetic preference than engineering majors. Kim (2007a) conducted a survey of 309 college students, and the major finding was that all students exhibited all six major learning styles. Their preferred learning styles were group, auditory, and tactile. Individual style was the least preferred one reported.

As seen from Lee (1995) and Kim (2007a), there was little consensus on learning style preferences even among groups of learners in the same educational context: university-level EFL learners in Korea. However, the findings of each study are significant on their own if learning style is considered a learning context-based individual difference. That is, rather than generalizing learning style preferences, learning context-based learning 
style identification and utilization for language instruction should be emphasized. It is also suggested that, for a more accurate and valid investigation of learning styles, multiple diagnostic instruments rather than single questionnaires should be considered.

Another field of learning style research involves empirical studies on the relationship between learning style and other variables (H. Kim, 2001; K. Kim 2007a; K. Kim, 2007b; J. Park, 1998; Y. Park, 1999; Park, Lee, \& Kang, 2005; Peacock, 2001; Thomas, Cox, \& Kojima, 2000). Tyacke (1998) argued that "recognizing learning style difference is only the first stage, however. Teachers must also provide appropriate paths in terms of syllabus design, choice of materials, and alternative assessments of proficiency" (p. 34). That is, the application of collected information on learning styles to other practical issues such as curriculum design, teaching styles, selection of materials, and performance assessment should be carefully considered.

Kim (2007a) investigated whether any relationship existed between learning styles and English achievement targeting 309 Korean university students. According to her results, based on multiple regression analysis, a significant relationship was predicted between individual/visual learning styles and better English achievement. In spite of this result, the author was cautious about the predictiveness of learning styles in terms of English improvement. It is uncertain that learning style is a causative factor in English achievement, either directly or indirectly. Since many other variables and factors are involved in language learning, a conclusive argument for the relationship between learning style and English achievement should be postponed.

Peacock (2001) conducted a survey with 206 Chinese learners in EFL classes and 16 teachers at Hong Kong University. Using Reid's PLSPQ (1987), the researcher found that the learners preferred styles were kinesthetic and auditory, and their least preferred styles were individual and group. In terms of teaching style, he used a self-modified teacher's version of the PLSPQ and found that kinesthetic and group styles were preferred by teachers, and tactile and individual styles were disfavored. According to the survey result, auditory and group styles were mismatched between learners and teachers. Additionally, the researcher conducted interviews with students and teachers and found that both students and teachers agreed with Reid's $(1987,1995)$ hypothesis: a mismatch between teaching and learning styles causes learning failure, frustration, and demotivation.

The present study aims to identify the characteristics of Korean EFL learners' perceptual learning styles for the following reasons. 1) Previous empirical research results on L2 learning styles have been mixed, so there is a need for further empirical studies. Fortunately, there has been renewed interest in designing learning style constructs since the late 1990s (Dörnyei, 2005). 2) Relevant studies that confirmed little or no effect on language achievement were mostly intended for children, whose styles may be unstable and continuously developing and undergoing change. With a target population of adult learners, the result might be significantly different. The participants for this study are university students, so studies on their learning styles is worthy of exploration.

\section{Research Design and Methodology}

\subsection{Participants}

A total of 496 EFL students from four different universities in Korea participated in the present study. Table 1 includes the background information of the participants.

Table 1. Overview of learner-subjects by university/gender/year/major

\begin{tabular}{lllllllllll}
\hline University & \multicolumn{3}{l}{ Gender } & \multicolumn{1}{l}{ Year } & \multicolumn{1}{l}{ Major } \\
\cline { 2 - 10 } & $\mathrm{M})$ & $\mathrm{F}$ & 1 & 2 & 3 & 4 & Lang. & Biz. & Engi. & Others \\
\hline A (328) & 138 & 190 & 80 & 26 & 130 & 92 & 45 & 136 & 47 & 100 \\
$\mathrm{~B}(54)$ & 34 & 20 & 1 & 53 & 0 & 0 & 0 & 0 & 43 & 11 \\
$\mathrm{C}(51)$ & 16 & 35 & 0 & 14 & 17 & 20 & 48 & 1 & 0 & 2 \\
D (63) & 39 & 24 & 37 & 6 & 5 & 15 & 18 & 7 & 25 & 13 \\
Total (496) & 227 & 269 & 118 & 99 & 152 & 127 & 111 & 144 & 115 & 126 \\
\hline
\end{tabular}

*Others (in terms of major) include humanities (13), social studies (24), law (17), art \& physical training (9), education (11), natural science (33), and medical science (19). 


\subsection{Instruments}

The research question can be answered by asking the 496 Korean learners to respond to 30 statements (translated into Korean) on learning styles (PLSPQ) using a five-point Likert scale (strongly agree $=5$, agree $=4$, undecided $=3$, disagree $=2$, and strongly disagree $=1$ ). As a result, Visual, Auditory, Tactile, Kinesthetic, Group, and Individual learning style could be identified as major, minor, or negligible according to the summed scores. Since Reid (1987; 1995) claimed that one's major learning style(s) represents how well the person learns best, the present study will adopt major learning style to identify each participant's primary learning style(s). Each learner may have one predominant major learning style, more than two major learning styles, or no distinct major learning style at all among the six perceptual learning styles previously outlined. Of the total participants, 125 responded to the PLSPQ twice, once at the beginning and again at the end of the semester in order to examine whether their preferred learning styles are consistent or changeable throughout the semester.

Also, the academic performances of the 125 subjects (2nd survey respondents) and 99 subjects (49 from the style-aware and 50 from the style-unaware group) were observed. Two types of scores are used for analysis: exam scores and term-end performance scores. The learners are scheduled to take the TOEIC test as the final exam for the course at the end of the semester, so their final TOEIC scores represent exam scores. A perfect score on the test is 990 . In addition, term-end performance scores are also adopted. Total performance scores consist of mid-term scores (30\%) and end-term scores $(30 \%)$, attendance $(20 \%)$, and quiz scores $(20 \%)$. A perfect score on the test is 100 . A pre-test was also implemented to verify homogeneity of the two groups: style-aware and style-unaware. A semi-TOEIC test was adopted for the pre-test, and it consists of 22 listening comprehension questions and 28 reading comprehension questions. The question items were excerpted from a set of mock TOEIC tests provided in the coursebook. TOEIC consists of 100 listening questions sub-divided into four parts and another 100 reading questions administered in three parts. The 50 question items for the pre-test were proportionally extracted from all seven parts, and two lecturers and the researcher reviewed the prepared set together.

\subsection{Data Analysis}

Data collection was carried out throughout the two semesters of 2012. The data were analyzed through SPSS 12.0 and Microsoft Office EXCEL 2007. Descriptive statistics, $t$-tests, one-way ANOVA, correlation coefficients (Pearson $r$ ), and factor analysis were carried out for data analysis.

\section{Results and Discussion}

\subsection{Analysis of Learning Style Preferences}

Means of six learning style preferences justifiably demonstrate which learning styles are favored by the respondents. Reid (1987) provided the referential preference means. According to Reid (1987), the mean scores of the preferred learning styles can be categorized as follows: 13.5 and above (major learning style preference), 11.50-13.49 (minor learning style preference), 11.49 or less (negligible learning style preference). The questionnaire consists of 30 question items, and each of the six learning styles is related to the five question items. Since the questionnaire is designed on a five point Likert scale, the score for each learning style can be reduced to the lowest 5 points and increased to the highest 25 points. As shown at Table 2, the learners for the present study are considered to have all the six major learning styles since they are all above 13.5. This result is equally applied to K. Kim (2007a), but in the case of Reid (1987), group (11.42) and individual style (12.46) were not included in major preference.

Table 2. Means of six learning style preferences

\begin{tabular}{lllllll}
\hline Leaning Style & Visual & Tactile & Auditory & Kinesthetic & Group & Individual \\
\hline Present study & 17.01 & 14.72 & 18.10 & 14.76 & 14.42 & 16.87 \\
K. Kim (2007a) & 15.51 & 15.75 & 15.90 & 15.68 & 16.44 & 14.86 \\
Reid (1987) & 14.07 & 14.48 & 13.73 & 14.58 & 11.42 & 12.46 \\
\hline
\end{tabular}

* 13.5 and above (major learning style)

The mean score of the auditory style is 18.10 , which means the learners are most likely to prefer to learn English with the help of auditory methods. Visual (17.01) and individual learning style (16.87) are also preferred learning styles. On the other hand, tactile (14.72), kinesthetic (14.76), and group learning styles (14.42) appear to 
be less favored. Kim (2007a) found that learners preferred group style (16.44) the most and individual style (14.86) the least. Reid (1987), however, showed that Korean ESL learners were most likely to learn kinesthetically (14.58) and group learning was the least favored. These different results may be due to the different learning contexts that the participants were in.

Correlation coefficient Pearson $r$ also explains the significant relationships between learning styles. First, tactile and kinesthetic learning styles are significantly related to each other, as shown by $\mathrm{r}=.74, p<.01$. Additionally, group and kinesthetic along with group and tactile learning styles are also significantly related to each other, as shown by $\mathrm{r}=.45, p<.01$, and $\mathrm{r}=.43, p<.01$, respectively. Correlations between 4.0 and 6.0 have both theoretical and practical value in education-related research, and the correlation of .65 or higher reasonably indicates a close relationship between the two variables correlated for most purposes (Frankel \& Wallen, 1993). The correlations obtained indicate that tactile, kinesthetic, and group learning styles are mutually related.

For an in-depth analysis of the common ground between the learners' learning style preferences, an exploratory factor analysis was carried out. According to the analysis, the six learning styles are reduced to two factors as shown in Table 3.

Table 3. Summary of factor loadings of learning style preferences

\begin{tabular}{llll}
\hline & \multicolumn{2}{l}{ Factor loadings (Rotated component matrix) } & \multirow{2}{*}{ Communality } \\
\cline { 2 - 3 } & Factor 1 & Factor 2 & .562 \\
Visual & .071 & $\mathbf{. 7 4 7}$ & .780 \\
Tactile & $\mathbf{. 8 7 5}$ & .118 & .134 \\
Auditory & .359 & -.068 & .791 \\
Kinesthetic & $\mathbf{. 8 8 5}$ & .091 & .605 \\
Group & $\mathbf{. 6 9 1}$ & -.358 & .704 \\
Individual & -.146 & $\mathbf{. 8 2 6}$ & \\
\hline
\end{tabular}

Among the six learning styles, auditory style is excluded since communality is low (below .40). As a result, tactile, kinesthetic, and group learning styles load onto factor 1, and visual and individual learning styles load onto factor 2 .

Table 4. Learning style preference factors

\begin{tabular}{lll}
\hline Factor & Learning style (factor 1) & Learning style (factor 2) \\
\hline Name of factor & Experience-driven collaborative & Visual-driven independent \\
Loaded style items & Tactile/Kinesthetic/Group & Visual/Individual \\
Preference means & 14.63 & 16.94 \\
\hline
\end{tabular}

As shown in Table 4, the two factors identified serve as indicators of experience-driven collaborative learning style and visual-driven independent learning style. The key feature of the two factors appears to be learners' preference of individual study mode or group study mode. It appears that tactile and kinesthetic learners are more likely to enjoy collaborative learning with peers, whereas visual learners rely on studying by themselves through visual materials. The mean scores of experience-driven collaborative learning style preferences and visual-driven independent learning style preferences are 14.63 and 16.94. These figures roughly suggest that the learners for the present study show more preference for visual-driven independent learning style than experience-driven collaborative learning style.

This seems reasonable in terms of accessibility. In the context of the present study, the learners are generally accustomed to using individual learning styles while reading or viewing language materials. Tactile and kinesthetic learning contexts are unusual in English language classes for examination preparation. That is, the learners are considered to prefer their context-dependent learning style. This interpretation explains the different patterns of learning style preferences of Korean students in ESL or EFL contexts and in communication classes or examination preparation classes.

According to the analysis by gender, male students have higher mean scores in tactile, kinesthetic, individual, 
and group style preferences than females. Female students have higher mean scores in visual and auditory style preferences. Levene's homogeneity test suggests that male and female students are significantly different groups in terms of kinesthetic learning style at the significance level below $p<.05$. Male students are more likely to utilize a kinesthetic learning style in English learning. The independent $t$-test also indicates that female learners have higher mean scores in the visual learning style preference, and the difference is statistically significant at the significance level below $p<.05$. Male students, on the other hand, have higher mean scores in kinesthetic and group learning style preferences, and the differences are also statistically different at the significance level below $p<.05$. All in all, the findings suggest that female learners are more visually sensitive than their male counterparts, and that male learners prefer to participate actively in their learning and cooperation with other learners facilitates male students' learning.

When the learners' major fields are placed in the position of independent variables, there is no significant difference in learning style preferences. The learners have the highest mean scores in auditory style regardless of their major fields. With regard to the lowest mean score among the six learning style preferences, language majors (Mean=13.89, $\mathrm{SD}=4.82$ ) and business majors (Mean=14.07, $\mathrm{SD}=4.11$ ) show that group learning style is the least favored, whereas engineering majors (Mean=15.22, $\mathrm{SD}=4.07$ ) have the lowest mean score in kinesthetic style preference.

Finally, differences in learning style preferences were analyzed depending on the learners' English proficiency (TOEIC scores). According to descriptive statistics, in terms of visual, tactile, kinesthetic, and individual styles, there is a tendency for learners with higher TOEIC scores to have higher mean scores of learning style preferences. This means that more advanced learners tend to be more active in using visual, tactile, kinesthetic, and individual learning styles. However, the mean scores of the auditory style preference are considered similarly high in all TOEIC score groups. For an in-depth analysis, inferential statistics were conducted. The result of ANOVA tests indicate that there are statistically significant differences among the groups with respect to TOEIC scores in visual, tactile, kinesthetic, and individual style preferences. Post-hoc tests were carried out in order to identify where specific differences exist. The result shows that in visual, tactile, and individual learning styles, the mean scores gap between low or no-experience groups and advanced groups is statistically significant at alpha level below $p<.05$. It is presumed that the no-experience group of learners consists of a substantial number of language-exam unprepared learners who are beginning level learners.

Consequently, it is assumed that more advanced learners are likely to be more visual-, tactile-, and individual-learning style sensitive. In case of auditory, kinesthetic, and group style preferences, however, the difference between mean scores is not statistically significant. It is believed that English proficiency does not significantly influence learners' preferences for auditory, kinesthetic, and group learning styles.

To this point the means of learning style preferences have been analyzed. Learning style preferences include all the learner-subjects' preference scores of the six learning styles; they represent the general trend of the learners' favored learning styles. The findings are as follows: 1) According to the mean scores of style preferences, all the six learning styles are considered major styles for their English learning, but the mean scores of auditory, visual, and individual learning style preferences are noticeably higher than those of tactile, kinesthetic, and group style. 2) Female learners are more likely to use visual learning styles and male learners are more represented by kinesthetic and group style preferences. 3) A significant difference due to major fields has not been found. 4) According to TOEIC scores, more advanced learners tend to be more visual, tactile, and individual style owners.

\subsection{Analysis of Major Learning Style}

In addition to learning style preferences, the learners' identified major learning style should represent the learners' learning style priorities. The 496 learners' major learning styles were identified by questionnaire. Table 5 provides descriptive information on how many major learning styles the learners are identified with. The three most predominant groups appear to be learners with one, two, and no major learning style. About one third of the participants (143 learners) are confirmed to be one major style owners (28.83\%). No major style is identified for 127 learners $(25.60 \%)$. Learners numbering 115 belong to the two major style group (23.19\%). The majority $(77.62 \%)$ of the learners in the present study belong to no, one, or two major learning style group. Synthetically, it appears that each learner has 1.56 identified major learning styles on average. 
Table 5. Number of identified major learning styles

\begin{tabular}{lllllllll}
\hline Major Learning styles (N) & 0 & 1 & 2 & 3 & 4 & 5 & 6 & Total \\
\hline Learners (N) & 127 & 143 & 115 & 63 & 31 & 13 & 4 & 496 \\
Percentage (\%) & 25.60 & 28.83 & 23.19 & 12.70 & 6.25 & 2.62 & 0.81 & 100 \\
\hline
\end{tabular}

The quantity of major learning styles were examined in detail with relevance to the learner's gender, major, and English proficiency through $t$-test and ANOVA. Noticeable gender differences are not apparent. Male students are considered to have 1.52 major learning styles on average and females 1.60. According to the learners' majors, language majors have 1.75 major learning styles, business majors 1.52, and engineering majors 1.48 on average. Language majors have larger numbers of major learning styles, but there is no statistical significance at the alpha level below $p<.05$. Therefore, major fields such as language, business, and engineering are not likely to critically influence the number of major learning styles.

The learner's gender and major do not make a significant difference regarding the number of major learning styles, whereas English proficiency seems to be relevant to the number of major learning styles. TOEIC score appear to be significantly associated with the number of major learning styles. The number of major learning styles is as follows: 1.09 for the "below 400" group, 1.23 for the " $400-595$ " group, 1.55 for the "600-795" group, and 2.21 for the "800-990" group. According to the results, the number of major learning styles increases as TOEIC scores rise. Notably, the number of major learning styles of the '800-990' group is statistically different from the other three groups at alpha level below $p<.05$. Consequently, based on these findings, it can be concluded that language majors and learners with advanced English proficiency tend to have more major learning styles.

As shown in Table 6, when the identified major learning styles are examined in detail, they appear to split into two groups: the numerical superiority of the auditory, individual, and visual styles and the numerical inferiority of the tactile, kinesthetic, and group styles.

Table 6. Number of learners by major learning style

\begin{tabular}{llllllll}
\hline Major learning Style & Visual & Tactile & Auditory & Kinesthetic & Group & Individual & Total \\
\hline Learner $(\mathrm{N})$ & 132 & 96 & 209 & 90 & 89 & 160 & 776 \\
\hline
\end{tabular}

It appears that the most preferred major style is auditory (209 learners). Individual style (160) and visual style (132) follow. Tactile style (96), kinesthetic style (90), and group style (89) are all similar in terms of size. This result indicates that the learners are relatively passive users of active and collaborative learning styles. This aspect is significantly different from Reid's (1987) conclusion that Korean learners generally prefer tactile and kinesthetic learning styles. The disparity between the two studies may be due to reasons such as the time of the survey, number of participants, and different distributions of the participants' gender, year, and major, among other factors. The learning context is another important factor that may have resulted in the disparity. Reid investigated ESL learners in the U.S., whereas the present study examined EFL learners in Korea.

The findings regarding major learning style indicate that 1) Most of the learners (about 74.4\%) have a major learning style(s) from one through six of the identified learning styles. More than two-thirds of the major learning style users have one or two learning styles. 2) Among the major learning styles, auditory, individual, and visual learning styles are much more preferred than tactile, kinesthetic, and group learning styles. Context and learning environment appears relevant to their favored major learning styles.

\subsection{Analysis of Change in Major Learning Style}

Whether the learners maintain their major learning style(s) or change them over the course of the semester was investigated through repeated measures. Among the 496 learners who participated in the first PLSPQ survey, 125 learners again responded to the second survey at the end of the semester; the interval between the survey implementation was three months. The second round of survey data was analyzed in the same manner as the first survey data analysis, and the results were compared with that of the first data analysis. 
Table 7. Change in the number of identified major learning style(s)

\begin{tabular}{lllllllll}
\hline \multicolumn{3}{l}{ 1st survey data } & \multicolumn{3}{c}{ Change } & \multicolumn{3}{l}{ 2nd survey data } \\
\hline $\begin{array}{l}\text { Major } \\
\text { style }\end{array}$ & $\begin{array}{l}\text { Learner } \\
(\mathrm{N})\end{array}$ & $\begin{array}{l}\text { Percentage } \\
(\%)\end{array}$ & Pattern & $\begin{array}{l}\text { Learner } \\
(\mathrm{N})\end{array}$ & $\begin{array}{l}\text { Percentage } \\
(\%)\end{array}$ & $\begin{array}{l}\text { Major } \\
\text { style }\end{array}$ & $\begin{array}{l}\text { Learner } \\
(\mathrm{N})\end{array}$ & $\begin{array}{l}\text { Percentage } \\
(\%)\end{array}$ \\
\hline 0 & 41 & 32.8 & maintain & 52 & 41.6 & 0 & 32 & 25.6 \\
1 & 46 & 36.8 & increase & 55 & 44 & 1 & 31 & 24.8 \\
2 & 22 & 17.6 & decrease & 18 & 14.4 & 2 & 27 & 21.6 \\
3 & 12 & 9.6 & & & & 3 & 16 & 12.8 \\
4 & 4 & 3.2 & & & & 4 & 12 & 9.6 \\
5 & 0 & 0 & & & & 5 & 5 & 4.0 \\
6 & 0 & 0 & & & & 6 & 2 & 1.6 \\
\hline
\end{tabular}

Table 7 summarizes the change in the number of identified major learning style(s). In the first survey the majority of the learners belonged to one, no, and two major learning style groups. However, in the second survey the distribution of the number of major learning styles is more varied and scattered from no major style to all six major styles. This result may be due to the fact that the learners became more conscious of their learning styles by the time the second survey was administered. The researcher provided the learners with general information about the perceptual learning styles, i.e., type of styles and the meaning of each style so that the learners could be more conscious of and try to pay more attention to their own learning styles. The comparative analysis of the first and second survey indicates that 52 out of 125 learners $(41.6 \%)$ maintained the same number of major learning style(s), 55 learners (44\%) increased their number of major learning style(s), and 18 (14.4\%) identified a decrease by the second survey.

When the changes are examined qualitatively, five different groups can be categorized in terms of the quality of change: no change, inclusive expansion, emergence, transfer, and decrease or disappear. Table 8 provides details of these changes.

Table 8 . The types of major learning style(s) modification

\begin{tabular}{llll}
\hline & Specific change & Number of learners & Percentage \\
\hline 1 & No change & 38 & 30.4 \\
2 & Inclusive expansion & 40 & 32 \\
3 & Emergence & 20 & 16 \\
4 & Transfer & 11 & 8.8 \\
5 & Decrease or disappear & 16 & 12.8 \\
& Total & 125 & 100 \\
\hline
\end{tabular}

Thirty-eight learners (30.4\%) did not change their major learning style(s) on the second response at all. Forty learners (32\%) expanded their major learning style(s) including their original(s). For example, a learner had a major visual style at first, but he or she added another major learning style(s) to the visual style at the second period. Twenty learners $(16 \%)$ who had no major style initially had one or some major learning style(s) in the second response. Eleven learners (8.8\%) transferred their major learning style(s) into a different one from their original responses the second time. The major learning style(s) of 16 learners $(12.8 \%)$ were withdrawn at the second survey.

To sum up, $62.4 \%$ of the learners maintained their first-identified major learning style(s) and added additional major learning style(s). $37.6 \%$ of the learners, however, showed a change of major learning style(s) from the original(s). The findings indicate that the learners' favored perceptual learning styles are changeable in some cases, i.e., the learners may want to use different learning styles depending on time and situation. Nevertheless, the fact that more than half of the learners are likely to prefer one specific major learning style(s), and then add an additional learning style(s) as time goes by, suggests that there exists in the learners' salient characteristics regarding preferred major learning styles.

How the identification of major learning styles is qualitatively different between the two times is shown in Table 
9. As previously noted, the total number of the major learning styles increased.

Table 9. Change in number of learners by major learning style

\begin{tabular}{llllllll}
\hline Major style & Visual & Tactile & Auditory & Kinesthetic & Group & Individual & Total \\
\hline $1^{\text {st }}$ survey & 20 & 11 & 61 & 13 & 14 & 23 & 142 \\
& $(14.08 \%)$ & $(7.74 \%)$ & $(42.96 \%)$ & $(9.15 \%)$ & $(9.86 \%)$ & $(16.20 \%)$ & \\
change & +18 & +15 & -5 & +19 & +13 & +16 & +76 \\
$2^{\text {nd }}$ survey & 38 & 26 & 56 & 32 & 27 & 39 & 218 \\
& $(17.43 \%)$ & $(11.93 \%)$ & $(25.69 \%)$ & $(14.68 \%)$ & $(12.39 \%)$ & $(17.89 \%)$ & \\
\hline
\end{tabular}

In the first survey, 142 major learning styles were identified, and it increased to 218 in the second survey. It appears that one learner has 1.14 major learning styles in the first survey, and he or she has 1.74 major learning styles on average in the second survey. This is relevant to $32 \%$ of learners who expanded their number of major learning styles in the second survey. Except for auditory style, all the learning styles increased in number. Auditory learning style is the most preferred major style in both survey results, and individual and visual learning styles are followed. That is, the primary tendency on major learning styles appears unchanged.

The correlation coefficient Pearson $r$ measured for six learning style pairs between the learning style preferences of the first survey and the second survey indicates that there is a moderate level of positive correlation (average $r=.56$ ). Tactile and group learning style preferences show the highest correlations ( $r=.64$ for both). For kinesthetic, individual, and auditory learning style preferences, they were measured as $r=.63, r=.60$, and $r=.48$, respectively. Visual learning style preferences show the lowest correlation $(r=.39)$. These findings suggest that the learners generally have consistent learning style preferences, especially in terms of tactile, group, kinesthetic, and individual learning styles.

In summation, about $30 \%$ of the learners maintained their original major learning style(s) throughout the semester, and $32 \%$ increased and modified their preferred major learning styles after three months beyond the first-identified major learning style(s). In other words, $62 \%$ of the learners have their own firmly-held beliefs of their major learning style preferences, and their major learning styles tend to be reinforced. Moreover, the learners increased their level of preference in visual, tactile, kinesthetic, and individual learning styles after being informed of perceptual learning styles. The process itself whereby learners deliberate on what learning style they favor should benefit the learners in that it may help them manage and reinforce their own learning while utilizing relevant learning materials accordingly.

\subsection{Modification of Major Learning Style and English Achievement}

Whether the modification of major learning style within the period of one semester is related to their English achievement can be examined through a one-way ANOVA test. Five style-modification categories provided in Table 8 is considered the independent variable, and the learners' final exam scores are the dependent variable. Among 125 subjects, 89 learners attended TOEIC for Employment, a compulsory subject that any student can enroll in, and 36 learners were from TOEIC advanced, an elective course that only upper-intermediate or advanced students can join. Table 10 shows the mean scores of the learners' final exam scores in each course by modification categories.

Table 10. Mean scores of final exam on two courses by modification categories

\begin{tabular}{lllll}
\hline Course & \multicolumn{2}{c}{ TOEIC for employment } & \multicolumn{2}{c}{ TOEIC advanced } \\
Style modification & $\mathrm{N}$ & Mean scores (rank) & $\mathrm{N}$ & Mean scores (rank) \\
\hline No change & 31 & $474.03(1)$ & 7 & $761.42(1)$ \\
Inclusive expansion & 24 & $405.63(3)$ & 16 & $720.31(2)$ \\
Emergence & 12 & $405(4)$ & 8 & $703.13(3)$ \\
Transfer & 11 & $391.43(5)$ & 4 & $702.5(4)$ \\
Decrease or disappear & 7 & $417.33(2)$ & 1 & $690(5)$ \\
Total & 89 & 418.68 & 36 & 715.47 \\
\hline
\end{tabular}

* Perfect score: 990 
According to the results, for both courses, the no change group shows the highest mean scores at 474.03 and 761.42 , respectively. The inclusive expansion group shows the second highest mean scores in the TOEIC Advanced class, and the third highest mean scores in the TOEIC for Employment class. This indicates that the learners are likely to obtain better English achievement when they maintain the same major learning style(s) or inclusively expand them throughout the course. The learners from the transfer group and the decrease or disappear group generally show low mean scores except the moderate scores (417.33) from decrease or disappear group of TOEIC for Employment. This may suggest that the learners who completely replace their original learning style(s) with different ones, or decrease or abandon their original major learning styles, tend to make relatively modest test result gains. However, a hasty generalization should not be made since the ANOVA test results do not support this interpretation. In both cases, the differences between the mean scores among the groups are not statistically different.

To sum up, the learners who maintain constant learning style(s) such as no change or inclusive expansion throughout the semester may experience relatively higher English achievement. However, a statistical interpretation of whether the modification of major learning styles is related to English achievement should be delayed until later research.

\subsection{Learners' Awareness of Identified Learning Style and Learning Results}

Whether the learners' awareness of their identified learning styles helped them achieve better learning results in the English language course was also checked. The 99 learners from two classes of TOEIC for Employment are the subjects. One class, consisting of 49 students, were not informed of their learning styles identified by the survey (Group A), and the other class consisting of 50 students are informed (Group B). The announcement was made through an in-class verbal announcement and a written notice through an e-class bulletin board at the same time so that the learners who want to confirm or recheck their own learning styles could access the information at any time. Except for whether or not their learning styles are announced, all remaining conditions are the same for both classes.

First, before the course begins, the learners of both classes take a pre-test. A perfect score on the test is 50 . According to the result of Levene's equal variance test, mean scores of Group A (unaware) and B (aware) are 26.36 and 27.13. The result of Levene's test confirms the homogeneity of the two groups with an alpha level of .05 . Therefore, even though the subjects of the two groups are not randomly assigned, they are considered homogeneous.

In order to investigate whether awareness of identified learning styles helps learners obtain better learning outcomes, independent $t$-tests were used. Table 11 shows the results of the $t$-tests.

Table 11. Result of $t$-test scores depending on learning style awareness

\begin{tabular}{|c|c|c|c|c|c|c|c|}
\hline \multirow{2}{*}{ Type (perfect score) } & \multirow{2}{*}{ Group } & \multirow{2}{*}{ Mean } & \multirow{2}{*}{ SD } & \multicolumn{2}{|c|}{ Levene's test } & \multicolumn{2}{|c|}{$t$-test } \\
\hline & & & & $F$ & $p$ & $t$ & $p$ \\
\hline \multirow{2}{*}{ 1. End-term exam. (990) } & $A(n=49)$ & 437.96 & 120.49 & \multirow{2}{*}{.89} & \multirow{2}{*}{.35} & \multirow{2}{*}{-.06} & \multirow{2}{*}{.95} \\
\hline & $\mathrm{B}(\mathrm{n}=50)$ & 439.40 & 96.41 & & & & \\
\hline \multirow{2}{*}{ 2. Performance score (100) } & $A(n=49)$ & 70.63 & 13.87 & \multirow{2}{*}{.17} & \multirow{2}{*}{.68} & \multirow{2}{*}{-.88} & \multirow{2}{*}{.38} \\
\hline & $\mathrm{B}(\mathrm{n}=50)$ & 73.08 & 13.70 & & & & \\
\hline
\end{tabular}

Two types of scores were adopted to compare the mean differences between the groups. First, the learners' end of term examination scores (TOEIC scores) were compared. As shown, the mean scores of group B (aware) is higher than that of group A (unaware), but the result of the $t$-test indicates that there exists no significant difference with an alpha level of .05. In other words, it is not possible to claim conclusively that the learners' awareness of their own preferred learning style(s) influences their examination results at the end of the semester. Another vehicle to compare the two groups is the learners' course performance scores. Since the learners' grades are rated based on this score, the performance scores can be considered an indicator of the learners' learning results over the semester. As shown, the mean of performance scores of Group B (aware) is higher than that of Group A (unaware). However, the significance of the difference is not confirmed in this case either with an alpha level of .05 .

Consequently, it would be premature to claim that awareness of the learners' identified learning styles help them obtain better learning results. It appears that the learners who are aware of their identified learning styles succeed 
in obtaining higher scores on both end of term exams and performances than uninformed learners, but the difference is not statistically significant. It is suggested that further studies are conducted to explain this causality.

\section{Conclusion}

Korean university-level EFL learners are sufficiently dynamic to utilize all six learning styles as major, although with more preference for auditory, visual, and individual than kinesthetic, tactile, and group. Therefore, multiple learning resources should be considered for effective English learning and teaching. However, learners' preferences for auditory, visual, and individual learning styles to kinesthetic, tactile, and group learning styles suggests that Korean learners are likely to remain conventional language learners. This postulation is based on 496 participants' responses that can be generalized within the Korean context.

The learners' strong preference for auditory learning style in the present study differs from the preconceived idea of Korean learners' visual-preference. There is a possibility that the change of learning environment could be relevant to this finding. Learning style is considered an individual difference that is caused by innate traits or nurtured characteristics. In terms of the nurture nature of learning style, it is convincing that a change of learning environment, such as an evolution of learning tools and materials, and learners' easier access to high-tech equipment may affect learning style preferences. Korean EFL learners' preference for the visual-style found in earlier studies, therefore, might be relevant to the traditional learning practice of the time, which can be represented in visual-oriented methodologies such as grammar-translation or text-based learning. The preference for an auditory-style found in the present study can be understood in the same context. Due to advances in technology and the widespread availability of audio-visual aids, auditory materials were easily adopted for English learning, which might have resulted in a change of learning style preferences. Further studies should be conducted.

Importantly, learning style should be understood considering the learners' learning context. Generalizations by ethnic group should be made carefully. One of the reasons why learning styles have been under-researched and remain outside the main concern of SLA researchers appears to be due to the failure to generalize learning style preferences according to ethnic group. Generalization of learning style preferences under the same ethnicity is dangerous because even learners within the same ethnic group study in different contextual settings, and these settings can influence the learners' development of learning style preferences. Rather, learning style preferences within the consideration of learning context, such as ESL or EFL, and communicative competence-focused or exam preparation-focused appears a more reasonable option. Both teachers and learners can benefit from the consideration of preferred learning styles relative to learning context.

\section{Acknowledgements}

This research is financed by Hankuk University of Foreign Studies Research Fund of 2014.

\section{References}

Arter, J. A., \& Jenkins, J. A. (1979). Differential diagnosis-prescriptive teaching: A critical appraisal. Review of Educational Research, 49, 517-555. http://dx.doi.org/10.2307/1169984

Brown, H. D. (1973). Affective variables in second language acquisition. Language Learning, 23, 231-244. http://dx.doi.org/10.1111/j.1467-1770.1973.tb00658.x

Brown, H. D. (2000). Principles of language learning and teaching (4th ed.). New York, NY: Longman.

Chapelle, C., \& Green, P. (1992). Field independence/dependence in second language acquisition research. Language Learning, 42, 47-83. http://dx.doi.org/10.1111/j.1467-1770.1992.tb00700.x

Chapelle, C., \& Roberts, C. (1986). Ambiguity tolerance and field independence as predictors of proficiency in English as a second language. Language Learning, 36, 27-45. http://dx.doi.org/10.1111/j.1467-1770.1986.tb00367.x

Cohen, A. D. (2002). Preparing teachers for styles- and strategies-based instruction. In V. Crew, C. Davison, \& B. Mak (Eds.), Reflecting on language in education (pp. 49-69). Hong Kong: The Hong Kong Institute of Education.

Cohen, A. D., Oxford, R. L., \& Chi, J. C. (2001). Learning style survey. Retrieved from http://www.carla.umn.edu/maxsa/documents/LearningStyleSurvey_MAXSA_IG.pdf

Cornett, C. (1983). What you should know about teaching and learning styles. Bloomington, IN: Phi Delta Kappa. 
Dörnyei, Z. (2005). The psychology of the language learner: Individual differences in second language acquisition. Mahwah, NJ: Lawrence Erlbaum Associates, Inc. http://dx.doi.org/10.1177/0261927X05281424

Dörnyei, Z. (2006). Individual differences in second language acquisition. AILA Review, 19, 42-68. http://dx.doi.org/10.1075/aila.19.05dor

Dörnyei, Z., \& Skehan, P. (2003). Individual differences in second language learning. In J. D. Catherine, \& M. H. Long (Eds.), The handbook of second language acquisition (pp. 589-630). Oxford, England: Blackwell Publishing. http://dx.doi.org/10.1002/9780470756492.ch18

Ehrman, M. E., \& Leaver, B. L. (2003). Cognitive styles in the service of language learning. System, 31, 391-415. http://dx.doi.org/10.1016/S0346-251X(03)00050-2

Frankel, J. R., \& Wallen, N. E. (1993). How to design and evaluate research in education (2nd ed.). New York, NY: McGraw-Hill.

Hansen, J. (1984). Field dependence-independence and language testing: Evidence from six Pacific Island cultures. TESOL Quarterly, 18, 311-324. http://dx.doi.org/10.2307/3586696

Hansen, J., \& Stansfield, C. (1981). Relationship of field dependent-independent cognitive styles to foreign $\begin{array}{lllll}\text { language } \quad \text { achievement. } & \text { Language }\end{array}$ http://dx.doi.org/10.1111/j.1467-1770.1981.tb01389.x

Hyland, K. (1994). The learning styles of Japanese students. JALT Journal, 16, 55-74.

Irvine, J. J., \& York, D. E. (1995). Learning styles and culturally diverse students: A literature review. In J. A. Banks, \& C. A. Banks (Eds.), Handbook of research on multicultural education (pp. 484-497). New York, NY: Macmillan.

Joy, S., \& Kolb, D. A. (2009). Are there cultural differences in learning style? International Journal of Intercultural Relations, 33, 69-85. http://dx.doi.org/10.1016/j.ijintrel.2008.11.002

Kampwirth, T. J., \& Bates, M. (1980). Modality preference and teaching methods: A review of the research. Academic Therapy, 15, 597-605.

Kavale, K. A., \& Forness, S. R. (1987). Assessing the efficacy of modality testing and teaching. Exceptional Children, 54, 228-239.

Kim, H. (2001). Language learning strategies, learning styles, and beliefs about language learning of Korean university students. Journal of Pan-pacific Association of Applied Linguistics, 5(1), 31-46.

Kim, K. (2007a). Predicting English achievement using learning styles of Korean EFL college students. English Language \& Literature Teaching, 13(1), 27-46.

Kim, K. (2007b). Validating the learning style structure in the PLSPQ for Korean EFL students. English Language Teaching, 19(3), 25-46.

Kim, Y. (1995). Korean ESL learners' learning styles and learning strategies. English Language Teaching, 4(1), 161-178.

Keefe, J. W. (1979). Student learning styles: Diagnosing and prescribing programs. Reston, VA: National Association of Secondary School Principals.

Lee, H. (1995). Learning styles preferences of university students. English Language Teaching, 4(1), 141-160.

Ma, R., \& Oxford, R. (2014). A diary study focusing on listening and speaking: The evolving interaction of learning styles and learning strategies in a motivated, advanced ESL learner. System, 43, 101-113. http://dx.doi.org/10.1016/j.system.2013.12.010

Melton, C. D. (1990). Bridging the cultural gap: A study of Chinese students' learning style preferences. RELC Journal, 21, 29-54. http://dx.doi.org/10.1177/003368829002100103

Oxford, R. L. (1993). Style analysis survey (SAS). Tuscaloosa, AL: University of Albama.

Oxford, R. L. (2001). Language learning styles and strategies. In M. Celce-Murcia (Eds.), Teaching English as a second language (pp. 359-366). Boston, MA: Heinle \& Heinle.

Oxford, R. L., \& Anderson, N. J. (1995). A crosscultural view of learning styles. Language teaching, 28, 201-215. http://dx.doi.org/10.1017/S0261444800000446

Park, C. (2002). Crosscultural differences in learning styles of secondary English learners. Bilingual Research 
Journal, 26, 213-229. http://dx.doi.org/10.1080/15235882.2002.10668720

Park, J. (1998). Do native speakers' teaching styles match to the learning styles of Korean middle- and high-school students in the English classroom? Foreign Languages Education, 5(1), 133-157.

Park, Y. (1999). An analysis of interrelationship among language learning strategies, learning styles, and learner variables of university students. English Teaching, 54(4), 281-308.

Park, J., Lee, G., \& Kang, M. (2005). The effects of cognitive style and vocabulary learning strategies on students' achievements in web-based learning. English Language \& Literature Teaching, 11(4), 21-47.

Peacock, M. (2001). Match or mismatch? Learning styles and teaching styles in EFL. International Journal of Applied Linguistics, 11, 1-20. http://dx.doi.org/10.1111/1473-4192.00001

Reid, J. M. (1987). The learning style preferences of ESL students. TESOL Quarterly, 21, 87-111. http://dx.doi.org/10.2307/3586356

Reid, J. M. (1995). Perceptual learning style preference survey. In J. Reid (Eds.), Learning styles in the ESL/EFL classroom (pp. 202-204). Boston, MA: Heinle \& Heinle.

Reid, J. M. (1998). Understanding learning styles in the second language classroom. Englewood Cliffs, NJ: Prentice-Hall Regents.

Skehan, P. (1991). Individual differences in second language learning. Studies in Second Language Acquisition, 13, 275-298. http://dx.doi.org/10.1017/S0272263100009979

Snider, V. E. (1992). Learning styles and learning to read: A critique. Remedial and Special Education, 13, 6-18. http://dx.doi.org/10.1177/074193259201300103

Song, D., \& Oh, E. (2011). Learning styles based on the different cultural background of KFL learners in online learning. Multimedia-Assisted Language Learning, 14(3), 133-154.

Stahl, S. A. (1999). Different strokes for different folks? A critique of learning style. American Educator, 23(3), 27-31.

Tarver, S. G., \& Dawson, M. M. (1978). Modality preferences and the teaching of reading: A review. Journal of Learning Disabilities, 11, 17-29. http://dx.doi.org/10.1177/002221947801100103

Thomas, H., Cox, R., \& Kojima, T. (2000, March). Relating preferred learning style to student achievement. Paper presented at the Annual Meeting of the Teachers of English to Speakers of Other Languages, Vancouver, Canada.

Tudor, I. (1996). Learner-centeredness as language education. Cambridge, England: Cambridge University Press.

Tyacke, M. (1998). Learning style diversity and the reading class: Curriculum design and assessment. In J. Reid (Eds.), Understanding learning styles in the second language classroom (pp. 34-45). Englewood Cliffs, NJ: Prentice-Hall Regents.

Willing, K. (1988). Learning styles in adult migration education. Adelaide, Australia: National Curriculum Resource Centre.

\section{Copyrights}

Copyright for this article is retained by the author(s), with first publication rights granted to the journal.

This is an open-access article distributed under the terms and conditions of the Creative Commons Attribution license (http://creativecommons.org/licenses/by/3.0/). 